\title{
Comparative Study on Implementing Home Air Conditioning for Passenger Carriages in the Indonesian Railway
}

\author{
Hardianto Eko Prasetio \\ Directorate General of Railways Ministry of Transportation, Jakarta, INDONESIA \\ elvisprasetio@gmail.com \\ Siti Malkhamah \\ Master Program in Transport System Engineering, Universitas Gadjah Mada, Yogyakarta, INDONESIA \\ malkhamah@ugm.ac.id \\ Charles Watson \\ School of Civil Engineering University of Birmingham, Birmingham, UK \\ c.watson.1@bham.ac.uk \\ Subarmono \\ Mechanical Engineering Department Universitas Gadjah Mada, Yogyakarta, INDONESIA \\ barmono@ugm.ac.id
}

\begin{abstract}
Passenger comfort is important in railway transport system. The train operator company in Indonesia would like to increase passenger comfort by installing home air conditioning into all existing carriages of the economy train. The air conditioning is expected to give better passenger convince. Therefore, the aims of this research are to know the cooling load and compare characteristic between home Air Conditioning (AC) and train AC. The cooling load calculation is analyzed using Cooling Load Temperature Difference (CLTD)/Solar Cooling Load (SCL)/Cooling Load Factor (CLF) method. Comparison between both home air conditioning and train air conditioning are discussed to identify the benefits and drawbacks of each type. The total heat that needs to be removed from a passenger carriage with home AC is $104,334 \mathrm{Btu} / \mathrm{h}$, while the total cooling capacity of home $\mathrm{AC}$ is $75,000 \mathrm{Btu} / \mathrm{h}$. The passenger carriages with train $\mathrm{AC}$ have cooling capacity $119,100 \mathrm{Btu} / \mathrm{h}$ to remove heat $11,5290 \mathrm{Btu} / \mathrm{h}$. The Energy Efficiency Ratio (EER) value of most home AC is higher than train AC, installation time of home $\mathrm{AC}$ is shorter than train AC, total cost for 20 years period of home AC is more than train AC. There is no guarantee for home $\mathrm{AC}$, so everything that happens to it will become the full responsibility of train operator company. The train AC control system is more effective than the home AC. No fresh air is permitted to circulate within the home AC system hence, the same air is repeatedly processed in the system. Implementing home air conditioning in the existing passenger carriages is worthwhile for short time period in the goal to increase and improve the level of service provided by giving better comfortability to the passenger.
\end{abstract}

Keywords: Air conditioning, cooling load, passenger carriage, CLTD/SCL/CLF.

\section{INTRODUCTION}

Indonesia is a developing country that is trying to build a better railway system. The Government, as rail infrastructure owner is continuing to build new rail infrastructure to develop railway links to increase railway routes. Additionally, train operating companies has attempted to increase the level of service by upgrading the train facilities. Indonesia as a tropical country with a mostly hot climate during the whole year highly requires air conditioning on the trains. Not all trains in Indonesian railway have air conditioning. The majority of the older passenger carriages do not have air conditioning. To cope with this problem, the train operating company of Indonesian railway provided home air conditioning to increase passenger satisfaction and comfort ability.
The train operating companies decided to use home air conditioning in the passenger train because of it is easier and faster to install. Subsequently, carriages do not need to stay in the workshop for a long time, as the installation can be done in the train depot. The train operating companies argue that using home air conditioning is cheaper than using train air conditioning, so the cost to build and maintain the air conditioning is reduced.

Factually, the home air conditioning is not designed to be used in the railway carriages; it is designed for static places like homes or buildings rather than for moving objects. Therefore there could be risks as a consequence of placing home air conditioning on the train. Before train operating company implemented home air conditioning on the train, there was no initial 
study conducted or engineering design made to cope with this plan. Therefore, it is important to conduct research on the implementation of home air conditioning on passenger carriages to find out how they perform and assess any associated risks or effects that might occur.

The main objective of this paper is to give suggestion to Indonesian Government to allow or not related to implementing home air conditioning in the train. There are several aims to achieve the objective of this research, i.e. to calculate the amount of heat that needs to be removed from the passenger carriage with full loaded, to compare the performance of home air conditioning and train air conditioning, and to identify the risks that could happen on implementing home air conditioning in the train.

\section{LITERATURE REVIEW}

\subsection{Air Conditioning}

According to ASHRAE (2016), the first functional definition of air conditioning was created by Wilson (1908). The definition was claimed by Willis Carrier, "father of air conditioning" as follow:

a) Maintain suitable humidity in a vehicle or a room.

b) Supply a constant and adequate of ventilation.

c) Release surplus humidity in the air during certain seasons.

d) Remove micro-organism from the air efficiently such as dust, soot, and other foreign bodies.

e) Cool indoor air efficiently during certain seasons.

f) Equipment that is not cost-prohibitive in purchase or maintenance.

The air conditioning also is known as HVAC \& $\mathrm{R}$. This is an abbreviation of Heating, Ventilating, Air Conditioning, and Refrigerating. All these individual component processes were developed before a complete concept of air conditioning.

\subsection{Mechanism of Air Conditioning}

Every air conditioner has got a compressor inside. The compressor function is to compress and pump the refrigerant gas. When the compressor compresses refrigerant gas, it produces heat. To dissolve this heat, compressed refrigerant is pumped to the condenser coils where a fan blows the heat out to the outer atmosphere. Refrigerant gas transforms into the liquid form during this process. Then, the liquid refrigerant is pumped to expansion valve. The expansion valve has a temperature sensor connected that works in correlation with thermostat settings. Then, the expansion valve releases the appropriate amount of refrigerant to the evaporator that consists of cooling coils. In this process, the liquid refrigerant becomes gas form. The transformation from a liquid into gas state due to expansion causes cooling because energy is absorbed by the surrounding. A fan blow air passes through fins that attached to coils. The air becomes cooler and spread to the room. The gaseous refrigerant in cooling coils then go to the compressor and compressed once again. The cycle keeps continuing unless the compressor is shut down (Talal, 2016).

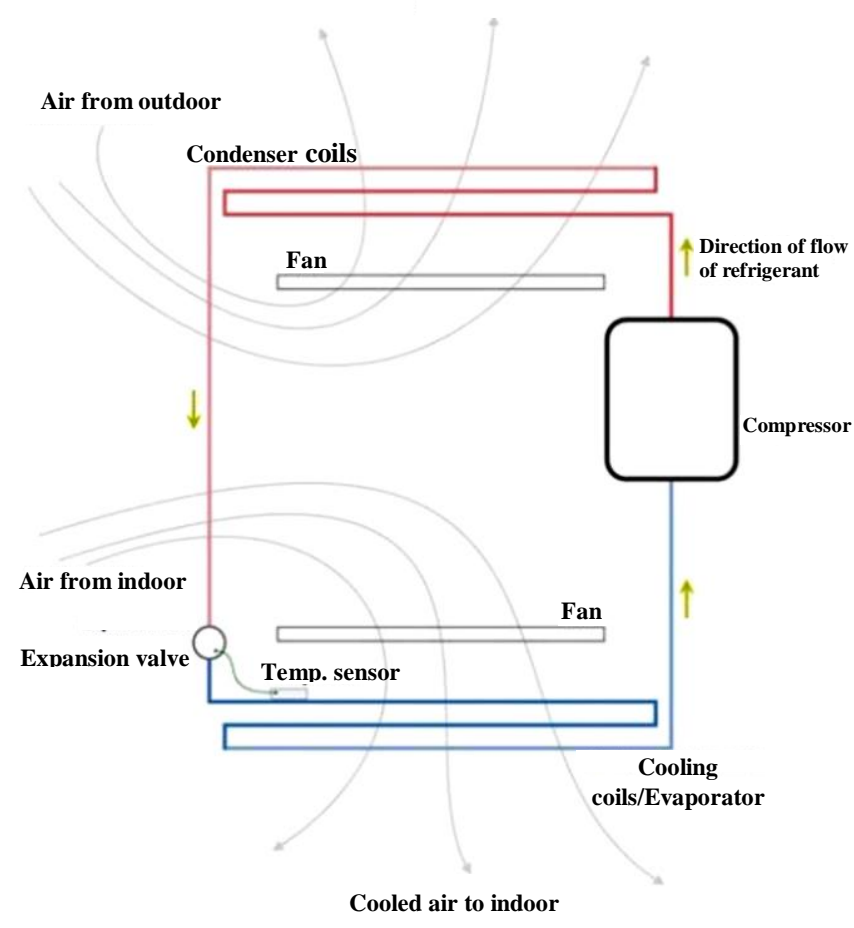

Figure 1. Principle Mechanism of Air Conditioning (Talal, 2016).

\subsection{Classification of Air Conditioning}

Air conditioners have several types that can be used for different applications. To choose the right type of air conditioners depends on several factors such as the size of the area is to be cooled, and total heat generated inside the enclosed area. The common commercial types of an air conditioner according to Khaemani (2016), as follow:

a) Window air conditioner.

b) Split air conditioner.

c) Packaged air conditioner.

d) Central air conditioning system.

\subsection{Train Air Conditioning}

Train Air Conditioning can be defined as air conditioners that designed for rail vehicle to altering the air inside the vehicle to meet the required condition. The objective is to create comfort ability for the passenger during the journey. 


\subsection{General Comfort Considerations}

Based on ASHRAE Standard 55, Thermal Environmental Conditions for Human Occupancy may be referenced to determine the train interior thermal environmental factors that will provide environmental condition acceptable to a majority of the passengers.

Simion, et al. (2016) explained about factors that influence the thermal comfort inside of vehicles and categorized the factors into two, i.e. :

a) Personal factors, characteristics of the occupants included activity level and clothing insulation level.

b) Measurable or environmental factors, conditions of the thermal environment included air velocity, air temperature, mean radiant temperature, and relative humidity.

All factors above have complex effects on the passenger's heat balance directly. They must be considered to gain conditions that will be perceived as comfortable by a majority of passengers (Prasetio, 2017).

\section{METHODOLOGY}

This paper was mostly based on the web study to find information and data that will be needed to address the problem. If possible, the interview will be held with staff from the train operating company and train manufacturer in Indonesia. A cooling load calculation will be provided using CLTD/SC/CLF method. The performance of the air conditioning will be calculated based on the specification of the air conditioning. Characteristic for both types of air conditioning will be compared to know the advantages and disadvantages. From the analysis, the main conclusion will be decided worth or not to use home air conditioning for passenger carriages.

\section{THEORETICAL BACKGROUND}

\subsection{Cooling Load}

The cooling load is calculated using CLTD/SCL/CLF method. Bhatia (2016) explained that LLTD, SCL, and SCL method include the effect of conductive heat gain through opaque exterior surfaces and thermal storage in converting radiant heat gain to the cooling load.

Cooling load calculations for air conditioning system design are mainly used to determine the volume flow rate of the air system as well as the coil and refrigeration load of the equipment. It is also to size the HVAC\&R equipment and to provide the inputs to the system for energy use calculations in order to select optimal design alternatives (Wang, 2001). Cooling load usually can be classified into two categories, namely external and internal.

\subsection{External Cooling Loads}

External loads consist of two types of heat transfer. The first one is conduction through the walls, roof, and windows. The second one is heat transfer by radiation through fenestration on windows glass and floor. Both of them are sensible heat transfers. The sensible heat transfer means the energy added to space by conduction, convection and/or radiation.

\subsubsection{Heat gain due to conduction}

Basic equations used to calculate heat gained by conduction is as follows (ASHRAE, 1997; 2014; 2016).

$$
Q=U \times A \times(C L T D)
$$

where $Q$ is cooling load or heat gain $(\mathrm{kcal} / \mathrm{h}), U$ is heat transfer coefficient for wall, window, roof $(\mathrm{kcal} / \mathrm{h}$ $\left.\mathrm{m}^{2}{ }^{0} \mathrm{C}\right), A$ is area of exterior wall, window, or roof $\left(\mathrm{m}^{2}\right)$, and CLTD is cooling load temperature difference $\left({ }^{0} \mathrm{C}\right)$.

\subsubsection{Heat gain due to radiation}

a) Solar load through glass

$$
Q=A \times(S C) \times(S C L)
$$

where $S C$ is shading coefficient, and $S C L$ is solar cooling load factor of glass without interior shade or with shade $\left(\mathrm{kcal} / \mathrm{h} \mathrm{m}^{2}\right)$.

b) Solar load through floor

$$
Q=U \times A \times\left(T_{a}-T_{r c}\right)
$$

where $T_{a}$ is the temperature in adjacent space $\left({ }^{0} \mathrm{C}\right)$, and $T_{r c}$ is inside design temperature in conditioned space $\left({ }^{0} \mathrm{C}\right)$.

If adjacent space or temperature is not suitable, use outdoor air temperature less $3{ }^{\circ} \mathrm{C}$. The design temperature in conditioned space assumed constant $25^{\circ} \mathrm{C}$

\subsection{External Cooling Loads}

\subsubsection{Heat gain from the passenger}

Cooling load that gained from the passenger consist of two parts which are sensible heat and latent heat (ASHRAE, 1997; 2014; 2016). 


$$
\begin{aligned}
& Q_{\text {Sensible }}=N \times\left(Q_{S}\right) \times(C L F) \\
& Q_{\text {Latent }}=N \times\left(Q_{L}\right)
\end{aligned}
$$

where $N$ is number of passengers, $Q_{S}$ is sensible heat gain from occupancy $(\mathrm{kcal} / \mathrm{h}), Q_{L}$ is latent heat gain from occupancy $(\mathrm{kcal} / \mathrm{h})$, and $C L F$ is cooling load factor, hour time of occupancy.

\subsubsection{Heat gain from the lights}

$Q_{e l}=3.41 \times W \times F_{u l} \times F_{s a} \times(C L F)$

where $W$ is power input from electrical lighting plans or lighting load data, $F_{u l}$ is lighting use factor, as appropriate, $F_{s a}$ is special allowance factor, as appropriate, and $C L F$ is cooling load factor.

\subsection{Total Heat to be Removed}

Besides external cooling load and internal cooling load, the total heat gain should consider the ventilation and infiltration.

\subsubsection{Passenger carriage with train AC}

Train AC usually installed on the coaches by train manufacturer company when the coaches are built. The carriages with train AC are designed with better insulation, so there is no infiltration air from outside. However, passenger train needs fresh air to make them feel more comfortable. Therefore, train AC unit has fresh air intake to blow the fresh air into the carriages.

$$
\begin{aligned}
& Q_{\text {Sensible }}=1.23 \times q \times\left(T_{o}-T_{i}\right) \\
& Q_{\text {Latent }}=3010 \times q \times\left(W_{o}-W_{i}\right)
\end{aligned}
$$

where $T_{i}$ is inside air temperature $\left({ }^{\circ} \mathrm{C}\right), W_{o}$ is outside air humidity ( $\mathrm{kg}$ water/kg dry air), and $W_{i}$ is inside air humidity (kg water/kg dry air).

\subsubsection{Passenger carriage with home AC}

The infiltration can be defined as air flow into the compartment through door open and leakage of partition. Unfortunately, the coach on the economy train does not have an automatic door. The door is manual handling that needs to be operated by people to open and close it. The door open condition time will vary depending on the passenger flow and attitude. Some irresponsible passengers that open the door does not close the door after through it. Therefore assumption has to be made for the heat gain from infiltration. The proposed value for infiltration is $20 \%$ of total heat gain.
Total heat gain $=$ External cooling load + Internal cooling load

Infiltration $=20 \% \times$ Total heat gain

\subsection{Cost analysis}

The cost analysis is consisting of two parts which are: initial cost and maintenance cost. The lifespan of home AC is assumed only 3 months while the train $\mathrm{AC}$ is designed for 20 years. Maintenance of home $\mathrm{AC}$ needs to be done every week, while for train AC every 6 months and overhaul every 4 years.

Initial cost $=($ price + installation $) \times$ unit

Maintenance $\cos t=$ maintenance $\times$ frequency $\times$ unit $(12)$

Overhaul cost $=$ overhaul $\times$ frequency $\times$ unit

\subsection{Performance of Air Conditioning}

\subsubsection{Energy Efficiency Ratio}

Each tool, as well as air conditioning, has an own measure of efficiency which is called the Energy Efficiency Ratio (EER). The EER for air conditioning can be calculated by dividing the average cooling capacity of the unit with the average power input of the unit.

\subsubsection{Energy Consumption}

The energy consumption is total power within time periods. While total power is power input multiplied by power factor. Energy consumption is usually measured in kilowatt-hours $(\mathrm{kWh})$.

Energy consumption=Power $\times$ Power Factor $\times$ Time $(14)$

The operation of the train can be assumed 14 hours a day. Assumption needs to be made for power factor of home $\mathrm{AC}$ which is 0.8 . While power factor for train $\mathrm{AC}$ can be calculated using Equation 15.

Power factor $=\frac{P}{\sqrt{3} \times V \times I}$

where $P$ is power input (Watt), $V$ is voltage (Volt), and $I$ is current (Ampere).

\subsection{Risk identification}

Risk $=$ Probability $\times$ Impact

Probability is how often the things happen. The impact is how big the result or effect of the things that happen. Classification of the risk can be seen in Table 1. 
Table 1. Risk level classification

\begin{tabular}{|c|c|}
\hline Level of risk & Condition \\
\hline Low & $\begin{array}{l}\text { There is no significant impact which } \\
\text { means does not decrease the passenger } \\
\text { satisfying and do not disturb the train } \\
\text { operation. }\end{array}$ \\
\hline Medium & $\begin{array}{l}\text { There is a value impact to the passenger. } \\
\text { Create dissatisfied of passenger and } \\
\text { disturb the train operation, but there are } \\
\text { no injuries people. }\end{array}$ \\
\hline High & $\begin{array}{l}\text { There is a big impact to the passenger } \\
\text { and train operating company. Creates } \\
\text { accident that disturbs the train operation } \\
\text { that needs rescheduling. There is injuries } \\
\text { people and broken of infrastructure and } \\
\text { rolling stock. }\end{array}$ \\
\hline
\end{tabular}

\section{AIR CONDITIONING IN INDONESIAN RAILWAY}

In Indonesia which has a tropical climate, the train air conditioning usually only have the ability to cooling the air temperature without heating capability. There is a train manufacturer in Indonesia which called PT Industri Kereta Api that produces rail vehicle mostly for the domestic market. For the air conditioning part, PT Industri Kereta Api has cooperation with one of train air conditioning manufacturer that already spread its products around the world. One type of air conditioning that produces by one company and mostly used in passenger carriages in Indonesia is RPU-6035V. Train air conditioner that commonly used on the passenger train in Indonesia is RPU$6035 \mathrm{~V}$ with quantity two units in each carriage. The specification of this air conditioner can be seen in Table 2.

Table 2. Railway air conditioning type RPU-6035V specification (Toshiba, 2011)

\begin{tabular}{lll}
\hline Item & & Performance \\
\hline AC Main circuit & Voltage & 3 phase $380 \mathrm{~V}$ \\
& & AC \\
& Frequency & $50 \mathrm{~Hz}$ \\
Air conditioning & & $17.5 \mathrm{~kW}$ or more \\
capacity & & $(15,000 \mathrm{kcal} / \mathrm{h})$ \\
Air flow rate & Circulation & $35 \mathrm{~m}^{3} / \mathrm{min} / \mathrm{unit}$ \\
& Return & $27 \mathrm{~m}^{3} / \mathrm{min} / \mathrm{unit}$ \\
& Fresh & $8.0 \mathrm{~m}^{3} / \mathrm{min} / \mathrm{unit}$ \\
Total operation & & $15.34 \mathrm{~A}$ \\
current & & $7.84 \mathrm{~kW}$ \\
Total input & & $1.5 \mathrm{~kg} / \mathrm{cycle}$ \\
power & & \\
Refrigerant & R-407C & \\
\hline
\end{tabular}

Train AC consists of several components that connected and collaborated to provide comfort air condition in the coach. Difference type of train AC could have slightly different component. However, the mechanism is still same. The main component of train $\mathrm{AC}$ roof mounted can be list below.

a) Compressor.

b) Condenser.

c) Evaporator.

d) Gauge panel.

e) Filter-Dryer.

f) Refrigerant.

g) Fresh air filters and returns air filter.

h) Temperature sensors and room temperature thermostat.

\subsection{Home Air Conditioning for Passenger Carriages}

Implementation of home air conditioning for passenger carriages in Indonesian railway started in 2012. The first train uses this kind of air conditioning is KA Sibinuang route Padang - Pariaman in West Sumatera. In the middle of 2013, PT KAI intends to install home air conditioning into all existing intercity train. PT KAI decides the type of home air conditioning used in passenger carriages in Indonesia be 1.5 PK with total six units for each coach. Typical specification of this air conditioning is shown in Table 3.

Table 3. Specification of typical home air conditioning (Panasonic, 2015)

\begin{tabular}{llll}
\hline Item & & Performance & Unit \\
\hline Cooling & EER & $12,500-$ & $\mathrm{Btu} / \mathrm{h}$ \\
capacity & & 12,700 & \\
& & $3.66-3.73$ & $\mathrm{~kW}$ \\
Electricity & Voltage & $10.4-10.2$ & $\mathrm{Btu} / \mathrm{h} \mathrm{W}$ \\
& Current & $220-240$ & $\mathrm{~V}$ \\
& Power & $1,200-, 250$ & $\mathrm{~W}$ \\
Moisture & & 2.2 & $\mathrm{~L} / \mathrm{h}$ \\
removal & & & \\
& & 4.6 & $\mathrm{Pt} / \mathrm{h}$ \\
Air flow & & 11.1 & $\mathrm{ft}^{3} / \mathrm{min}$ \\
& & 392 & $\mathrm{ft} / \mathrm{min}$ \\
Weight & Indoor & 9 & $\mathrm{~kg}$ \\
& Outdoor & 25 & $\mathrm{~kg}$ \\
\hline
\end{tabular}

\subsection{Installation}

\subsubsection{Indoor part}

Indoor part is one part of home air conditioning located in the room that needs to be conditioned. The indoor part is also called as cool part because the warm air inner room turns cool. There is two scheme of installation indoor part of home AC depending on the shape of the roof platform, such as flat, or curve one.

\subsubsection{Outdoor part}

The installation of home air conditioning can be done in the train depot. At the first time installation of air 
conditioning, there is no guidance to put the outdoor part. Some of the depots even locate the outdoor part at one of the carriage doors and shut off that door. This condition will decrease mobility of the passenger to enter or exit the carriage because one of the doors is forbidden. PT KAI decided to remove this scheme and move the outdoor parts in a better location. Then the idea is to put the outdoor part of air conditioning on under the frame. The outdoor units are placed in the bracket, and the brackets are screwed or welded under frames.

\section{RESULTS AND DISCUSSIONS}

\subsection{Cooling Load Calculation}

a) External Cooling Load

External cooling load $=$ Heat gain from conduction + Solar load

$$
\begin{aligned}
& =5,576.87+5,162.64 \\
& =10,739.51 \mathrm{k}-\mathrm{Cal} / \mathrm{h} \\
& =42,635.85 \mathrm{Btu} / \mathrm{h}
\end{aligned}
$$

b) Internal Cooling Loads

Internal cooling load $=Q_{\text {Sensible }}+Q_{\text {Latent }}+Q_{e l}$

$$
\begin{aligned}
& =6,374.84+4,240+546.17 \\
& =11,161.01 \mathrm{k}-\mathrm{Cal} / \mathrm{h} \\
& =44,309.21 \mathrm{Btu} / \mathrm{h}
\end{aligned}
$$

c) Total Heat to be Remove

Beside external cooling load and internal cooling load, the total heat gain should consider the ventilation and infiltration.

\section{Passenger coach with train AC}

Total heat $=$ External cooling load + Internal cooling load $+Q_{\text {Ventilation }}$

$$
\begin{aligned}
& =10,739.51+11,161.01+7,139.65 \\
& =29,040.17 \mathrm{k}-\mathrm{Cal} / \mathrm{h} \\
& =115,289.47 \mathrm{Btu} / \mathrm{h} \approx 115,290 \mathrm{Btu} / \mathrm{h}
\end{aligned}
$$

Passenger carriage with home AC

Total heat gain $=$ External cooling load + Internal cooling load

$$
=10,739.51+11,161.01
$$

$$
=21,900.52 \mathrm{k}-\mathrm{Cal} / \mathrm{h}
$$

Infiltration $=20 \% \times$ Total heat gain

$$
\begin{aligned}
& =0.2 \times 21,900.52 \\
& =4,380.1 \mathrm{kcal} / \mathrm{h}
\end{aligned}
$$

Total heat to be removed $=$ Total heat gain + Infiltration

$$
\begin{aligned}
& =21,900.52+4,380.1 \\
& =26,280.62 \mathrm{kcal} / \mathrm{h} \\
& =104,334.07 \mathrm{Btu} / \mathrm{h} \\
& \approx 104,334 \mathrm{Btu} / \mathrm{h}
\end{aligned}
$$

\subsection{Cooling Capacity and Cost}

Comparison of cooling performance and cost for each type of air conditioning can be seen in Table 4. It shows that changing the home AC unit with higher cooling capacity can remove the amount of heat.

Table 4. Cooling performance and cost

\begin{tabular}{lllll}
\hline & $\begin{array}{l}\text { Railway } \\
\text { AC }\end{array}$ & $\begin{array}{l}\text { Existing } \\
\text { home } \\
\text { AC } \\
1.5 \mathrm{PK}\end{array}$ & $\begin{array}{l}\text { Home } \\
\text { AC }\end{array}$ & $\begin{array}{l}\text { Home } \\
\text { AC }\end{array}$ \\
\hline $\begin{array}{l}\text { Quantity } \\
\begin{array}{l}\text { Cooling } \\
\text { capacity } \\
\text { each unit } \\
\text { (Btu/h) }\end{array}\end{array}$ & 59,550 & 12,500 & 18,800 & 24 PK \\
$\begin{array}{l}\text { Total } \\
\text { cooling } \\
\text { capacity } \\
\text { (Btu/h) }\end{array}$ & 119,100 & 75,000 & 112,800 & 145,200 \\
$\begin{array}{l}\text { Total heat to } \\
\text { be removed } \\
\text { (Btu/h) }\end{array}$ & 115,290 & 104,334 & 104,334 & 104,334 \\
\hline
\end{tabular}

Based on calculation, the home AC 2 PK which has cooling capacity $18,800 \mathrm{Btu} / \mathrm{h}$ was already enough, because the capacity minus heat of home AC $2 \mathrm{PK}$ is slightly higher than train AC. However, in implementation the train AC with $15,000 \mathrm{kcal} / \mathrm{h}$ will be replaced with $18,000 \mathrm{kcal} / \mathrm{h}$ so, the capacity minus heat will be higher than before. Another fact, the home AC implemented only for old carriages. Considering the old carriages, there is a possibility that actual cooling load is higher than calculation. Therefore, it is recommended to replace the existing home AC 1.5 PK with home AC 2.5 PK.

Table 4 also shows that the total cost in 20 years times period of home AC and train AC is hugely different. The cost of home AC is actually more expensive than 
the train AC. However, in short period, the cost of train AC more expensive than home AC. Replace the existing home AC 1.5 PK with home AC 2.5 PK will increase production cost charged to the train operator company. However, slightly increase of cost will increase the home AC performance significantly. Another benefit of use home AC, when one unit of the $\mathrm{AC}$ is broken the remaining unit of $\mathrm{AC}$ still provide enough cooling capacity to conditioning the air.

\subsection{Performance of Air Conditioning}

\subsubsection{Energy Efficiency Ratio}

Table 5 shows that higher cooling capacity of air conditioning needs higher power input to operate it. Air conditioning which has a higher value of cooling capacity and power input will have less EER value. It means that the air conditioning with high cooling capacity is not efficient as AC with lower cooling capacity. It also shows that the home AC is more efficient of energy than the train AC.

Table 5. Energy efficiency ratio of air conditioning

\begin{tabular}{|c|c|c|c|c|}
\hline & $\begin{array}{l}\text { Existing } \\
\text { home AC } \\
1.5 \text { PK (6 } \\
\text { unit) }\end{array}$ & $\begin{array}{l}\text { Home } \\
\text { AC } \\
2 \text { PK } \\
\text { (6 unit) }\end{array}$ & $\begin{array}{l}\text { Home } \\
\text { AC } \\
2.5 \text { PK } \\
\text { (6 unit) }\end{array}$ & $\begin{array}{l}\text { Train } \\
\text { AC } \\
\text { (2 unit) }\end{array}$ \\
\hline $\begin{array}{l}\text { Cooling } \\
\text { capacity } \\
\text { (Btu/h) }\end{array}$ & 75,000 & 112,800 & 145,200 & 119,100 \\
\hline $\begin{array}{l}\text { Power } \\
\text { input (W) }\end{array}$ & 7,200 & 11,700 & 15,900 & 15,680 \\
\hline $\begin{array}{l}\text { E.E.R. } \\
\text { (Btu/h W) }\end{array}$ & 10.42 & 9.64 & 9.13 & 7.60 \\
\hline
\end{tabular}

\subsubsection{Energy Consumption}

Table 6 shows that energy consumption of home air conditioning 1.5 PK, $2 \mathrm{PK}$, and 2.5 PK are increase along with increasing cooling activity. It means that higher cooling activity will spend more energy consumption. In the implementation, it will need bigger generator to supply enough electricity for air conditioning operation.

Table 6. Energy consumption of air conditioning per day at 14 hours

\begin{tabular}{|c|c|c|c|c|}
\hline & $\begin{array}{l}\text { Existing } \\
\text { home AC } \\
1.5 \text { PK (6 } \\
\text { unit) }\end{array}$ & $\begin{array}{l}\text { Home } \\
\text { AC } \\
2 \text { PK (6 } \\
\text { unit) }\end{array}$ & $\begin{array}{l}\text { Home AC } \\
2.5 \text { PK (6 } \\
\text { unit) }\end{array}$ & $\begin{array}{l}\text { Train AC } \\
\text { (2 unit) }\end{array}$ \\
\hline $\begin{array}{l}\text { Energy } \\
(\mathrm{kWh})\end{array}$ & 80.64 & 131.04 & 178.08 & 171.23 \\
\hline $\begin{array}{l}\text { Cooling } \\
\text { activity } \\
(\mathrm{Btu})\end{array}$ & $1,050,000$ & $1,579,200$ & $2,032,800$ & $1,667,400$ \\
\hline
\end{tabular}

The interesting part of Table 6 is about energy consumption of home air conditioning 2.5 PK and train air conditioning which are equal, but the cooling action of home air conditioning is higher than train air conditioning. It means that the home $\mathrm{AC}$ has less energy consumption than train AC. Less energy consumption will affect in less fuel consumption used for generator to supply electricity.

\subsection{Qualitative Analysis}

There are several things need to consider to choose type of air conditioning. These things including installation, lifespan, guarantee, controlling, air circulation, maintenance, and inspection. It becomes important factors that influence the investment of air conditioning and need to be analyzed.

\subsection{Installation}

Installation of home $\mathrm{AC}$ can be done in the depot with short of time and light equipment because the work is relatively simple. The roof structure does not need to change in order to add the air conditioning unit, no installation of the automatic door. To completely install home $\mathrm{AC}$, for one coach, it needs a time less than two weeks. With this short time, the process of installation does not disturb the train operation.

Installation of train air conditioning into existing train carriage will take longer time because the complexity of the jobs that need to be done. The structure of the roof must be changed to attach the air conditioning, need installation of automatic door movement, and sealing all parts of the coach. This work cannot be completed in the depot because of the lack of equipment. The work can be held on workshop or train manufacturer with a complete equipment and heavy tools to doing heavy jobs. Estimated time to install the train $\mathrm{AC}$ is two months. The longer time to install $\mathrm{AC}$ will have the possibility to disturb the train operation.

\subsection{Lifespan}

The train air conditioning has expected lifespan around 20 years. While for the home air conditioning, the lifespan varies depending on the maintenance and inspection. The lifespan of home air conditioning is predicted only three months less than one year. The lifespan will affect the whole cost of the air conditioning. The train AC with long lifespan has huge initial cost, and need a long time before replacing it with the new AC. While home AC has low initial cost but with a short lifespan that will need rapid change during the operation of the train and makes the whole cost will bigger. That is the reason 
there is an opportunity that the whole cost of the home $\mathrm{AC}$ could be slightly higher than the train AC.

\subsection{Guarantee}

The home air conditioning actually has a guarantee from the manufacturer. However, since the home air conditioning cannot implemented in the right way, the guarantee automatically broke and cannot be used. So, the train operator company has full responsibility for everything happened to home AC.

\subsection{Maintenance and Inspection}

Maintenance is an activity to keep the condition of machine or equipment so, it still can operate well. The home $\mathrm{AC}$ needs to be maintained more often than the train air conditioning. Some of parts of the home AC are located in under frame of the coach that will be dirty faster than another component in other location.

Inspection is an activity to check or identify the condition of our stuff. Inspection for home air conditioning is important because actually, it does not design for the train. The frequent inspection will be better to identify any possibility of malfunction that could happen with home AC. As soon as any unusual things happen and already identified, the solution to handle the problem can be arranged.

\subsection{Controlling}

The home air conditioning must be controlled individually to turn on or turn off the AC. As well as for setting the indoor temperature, need to be done one by one. While the train air conditioning is easier to control because it was centralize controlling. It is much simpler to turn on the $\mathrm{AC}$ and set the temperature. The train air conditioning has sensor and thermostat that controls the temperature continuously and warn if something unusual condition happens.

\subsection{Air Circulation}

Train air conditioning system has fresh air intake which means there is always fresh air join the AC circulation. The fresh air flowing into carriages in a certain amount depends on the train $\mathrm{AC}$ design. Unfortunately, the home air conditioning does not have a fresh air intake. So, the air circulation in the coach always uses the same air. In the small room with a lot of people like carriage, no fresh air for circulation could have bad effect on the passenger health.

\subsection{Comparison of Air Conditioning}

The comparison between home air conditioning and train air conditioning can be explained in Table 7. It shows comparison of train $\mathrm{AC}$ with home $\mathrm{AC}$ in several types. Train $\mathrm{AC}$ has advantages and drawbacks, while home $\mathrm{AC}$ also has their own advantages and drawbacks. Compare with existing home $\mathrm{AC}$, the train $\mathrm{AC}$ has superiority in cooling capacity, lifespan, manufacturer guarantee, central controlling, fresh air circulation, less maintenance, and inspection. While existing home AC has excess in power consumption, fast installation, and less initial cost.

Back to the main goal, the train operator company adding air conditioning system in the old passenger carriages is to increase the level of services. However, the installation of air conditioning is restricted by the time. This means that, although the train operator company has limited rolling stock, the installation should not disturb the train operation schedule so, fastest time installation is needed. Another restricted is the lifespan of the old carriages that will reach their limit in several years in front, so, spend a lot of money in investment to use air conditioning with long lifespan could be wasted decision. Because of this reason, even the train $\mathrm{AC}$ has more superiority than home $\mathrm{AC}$, the train operator company choose to use home $\mathrm{AC}$ for their old passenger carriages. However, the cooling capacity of existing home AC is less than train AC and not enough to remove the heat in the coach. Therefore, it is recommended for train operator company to replace the existing home AC $1.5 \mathrm{PK}$ with home AC 2.5 PK.

\subsection{Risks Identification}

According to the analysis result, risk level that may occur for each event is shown in Table 8. Maintenance and inspection are important to reduce the risks of implementing home $\mathrm{AC}$ in the passenger carriages. Both of them is responsibility of train operating company to keep the train service that satisfy the passenger and provide safety for the people. The train operating company must have maintenance and inspection program. Unfortunately after few years implementation of home air conditioning, the train operating company does not do the maintenance and inspection appropriately. It make the outdoor parts becomes rusty and dusty. This condition will affect the performance of home air conditioning. It is important to conduct the maintenance in the right way follow the schedule and procedure. Therefore, it is recommended for the train operating company to enhance their maintenance and inspection program. 
Table 7. Comparison of home AC and train AC

\begin{tabular}{|c|c|c|c|c|}
\hline Parameter & $\begin{array}{l}\text { Existing home } \\
\text { AC } 1.5 \mathrm{PK}\end{array}$ & Home AC 2 PK & $\begin{array}{l}\text { Recommended } \\
\text { home AC } 2.5 \mathrm{PK}\end{array}$ & Train AC \\
\hline Quantity of AC & 6 unit & 6 unit & 6 unit & 2 unit \\
\hline Cooling capacity each unit & $12,500 \mathrm{Btu} / \mathrm{h}$ & $18,800 \mathrm{Btu} / \mathrm{h}$ & 24,200 Btu/h & $59,550 \mathrm{Btu} / \mathrm{h}$ \\
\hline Total cooling capacity & 75,000 Btu/h & $112,800 \mathrm{Btu} / \mathrm{h}$ & $145,200 \mathrm{Btu} / \mathrm{h}$ & $119,100 \mathrm{Btu} / \mathrm{h}$ \\
\hline EER & $10.42 \mathrm{Btu} / \mathrm{h} / \mathrm{W}$ & 9.64 Btu/h/ W & 9.13 Btu/h/ W & $7.60 \mathrm{Btu} / \mathrm{h} / \mathrm{W}$ \\
\hline Total power input & $7,200 \mathrm{~W}$ & $11,700 \mathrm{~W}$ & $15,900 \mathrm{~W}$ & $15,680 \mathrm{~W}$ \\
\hline $\begin{array}{l}\text { Energy consumption per day } \\
(14 \mathrm{~h})\end{array}$ & $80.64 \mathrm{kWh}$ & $131.04 \mathrm{kWh}$ & $178.08 \mathrm{kWh}$ & $171.23 \mathrm{kWh}$ \\
\hline Installation time & Short & & & Long \\
\hline Installation place & Depot & & & $\begin{array}{l}\text { Workshop or train } \\
\text { manufacture }\end{array}$ \\
\hline Total cost 20 years & 3,456 Million IDR & 3,936 Million IDR & 4,896 Million IDR & 1,206 Million IDR \\
\hline Lifespan & Short & & & Long \\
\hline Guarantee & No & & & Manufacturer \\
\hline Maintenance and inspection & Often & & & Periodic \\
\hline Controlling & Individual & & & Centralize \\
\hline Air circulation & No fresh air & & & Fresh air intake \\
\hline
\end{tabular}

Table 8. Risk level of the event that could be occur

\begin{tabular}{llll}
\hline Event & \multicolumn{2}{l}{ Level of risk } & \\
\cline { 2 - 4 } & Low & Medium & High \\
\hline Fail component of & & $\sqrt{ }$ & \\
indoor part due to vibration & & & $\sqrt{ }$ \\
Outdoor part fall down & & & \\
due to vibration & & & \\
Flying ballast & $\sqrt{ }$ & \\
Dust and rust & $\sqrt{ }$ & \\
\hline
\end{tabular}

\section{CONCLUSIONS}

\subsection{Findings}

From the analysis on implementing home air conditioning in passenger carriage, there are some important findings as follow.

a) Base on calculation, the cooling load for existing passenger carriages economy train is 104,334 $\mathrm{Btu} / \mathrm{h}$. While the home air conditioning has total cooling capacity only $75,000 \mathrm{Btu} / \mathrm{h}$. The home AC cannot handle the cooling needed of the carriages. That is the reason why the passengers still feel warm.

b) Energy efficiency ratio for home $\mathrm{AC}$ is higher than train $\mathrm{AC}$. It means home $\mathrm{AC}$ is more efficient than train AC. Simply explains for this is that with equal power consumption, the home AC produce cooling capacity higher than train AC.

c) Installation of home $\mathrm{AC}$ needs shorter time which is less than two weeks and can be done in the depot. While train AC installation needs longer time estimated which is two months and can be completed in the workshop or train manufacturer. Longer installation of $\mathrm{AC}$ can disturb the train operation and will take few years to install it in all existing economy train.

d) Total cost for 20 years period of home AC is more than train AC, namely 3,456 Million IDR for 1.5 PK; 3,936 Million IDR for 2 PK, and 4,896 Million IDR for 2.5 PK. While the train AC cost about 1,206 Million IDR. It was a big difference cost for 20 years times period. If time period is shorter, the cost of home AC is less than train AC.

e) Guarantee for home $\mathrm{AC}$ was scorched since the $\mathrm{AC}$ installed on the rail vehicle because the home $\mathrm{AC}$ was not designated for moving an object with much vibration. If something happens to the home $\mathrm{AC}$, then the train operator take full responsibility.

f) The home AC needs maintenance and inspection more often than the train AC. Often maintenance is important to maintain the performance of the air conditioning and make the lifespan longer. Often inspection is required to identify the possibility of faulty or problem that could occur. This activity will increase the cost of maintenance and inspection that spend by train operator.

g) There is no fresh air intake in the home $\mathrm{AC}$ system. It means that the same air in the compartment is used continuously. This condition can create uncomfortable for some passenger.

h) The risk that could be occurs especially for outdoor parts that located under frame that will become rusty and dusty and possibly of falling down due to a lot of vibration. The connections between outdoor brackets and under frame are important to prevent the outdoor from falling down.

Based on findings that already explained in above, there can be concluded that home AC superior to train AC only in construction and initial cost. Implementation of home air conditioning in the 
passenger carriages is worth only for existing rolling stock in short time period, to increase the level of service and give better comfort ability to the passenger. However, several adjustments are required to achieve better performance.

\section{REFERENCES}

ASHRAE, 1997. ASHRAE Handbook 1997 Fundamental, Atlanta: ASRHAE.

ASHRAE, 2014. Guideline 23P. Guideline for the Design and Application of Heating, Ventilation, and Air Conditioning Equipment for Rail Passenger Vehicles, Atlanta: ASHRAE.

ASHRAE, 2016. Resources \& Publications. [Online] Available at: https://www.ashrae.org/ resources-publications/free-resources/top-ten- things-about-airconditioning

Bhatia, A., 2016. Cooling Load Calculations and Principles. CED.

Khemani, H., 2016. Bright Hub Engineering.. [Online]

Available at:
Panasonic, 2015. Air Conditioner 2015.. Jakarta: PT Panasonic Globel Indonesia.

Prasetio, H. E., 2017. Research on Implementing Home Air Conditioning for Passenger Carriages in the Indonesian Railway, Yogyakarta: Master Thesis, Faculty of Engineering, Universitas Gadjah Mada.

Simion, M., Socaciu, L. \& Unguresan, P., 2016. Factors which influence the thermal comfort inside of vehicles., Energy Procedia 85, pp. 472-480.

Talal, A., 2016. Mechanism and Principle of Air Conditioning - Easy Diagrammatic Explanaion. [Online]

Available at: http://benignblog.com/2012/01/how- airconditioner-works-simplediagrammaticexplanation.html

Toshiba, 2011. Technical Information Air Conditioning Unit for Indonesia. Madiun: Toshiba.

Wang, S. K., 2001. Air Conditioning and Refrigeration. New York: McGraw- Hill.

http://www.brighthubengineering.com/hvac/897-

types-of-air-conditioning-systems/ 